\title{
ESTABLISHMENT OF ENVIRONMENTAL STANDARDS OF PRODUCTION IN THE LAW OF THE EUROPEAN UNION
}

\section{Kachuriner V. L.}

\section{INTRODUCTION}

The use of harmful technologies is causing environmental pollution and its transformation both globally and on the European continent. It is considered appropriate to apply control over the effectiveness of legal norms governing industrial emissions into the environment. This can be facilitated by standardization, information cooperation and legal instruments and rules aimed at reducing the environmental impact of production and its products.

Environmental standards and principles for environmental protection are usually specified in regional and bilateral agreements, and detailed regulation, if necessary, is carried out at the national level. However, European Union law has a particularly significant impact on both international and national environmental law. The most intensive national and international regulation of environmental protection is carried out on the European continent, and the most successful environmental problem is solved in the context of European integration. This is evidenced by the legal experience of implementing environmental policy both at the level of the European Union and the Member States.

The analysis of the legislation of the European Union in the field of environmental protection is important for further improvement and increase of efficiency of the ecological legislation of Ukraine. The priority of Ukraine's cooperation with the European Union will also have practical significance achieving the goal of increasing the level of production productivity, expanding the base of its economic growth and competitiveness. This determines the need and relevance of the study of legal regulation of environmental policy of the European Union in the field of production.

Today, the results of the study of the development of EU environmental activities are used to analyze trends in modern environmental development and the state of environmental competence. Therefore, in order to better understand the existing environmental standards of production in the law of the European Union, it is necessary to consider in more detail the process of formation and development of EU environmental policy in general.

Standards are the main tool of government activities to avoid pollution. The formation of environmental standards of production in the law of the European Union has undergone certain stages in its development. 


\section{Pollution prevention}

In the early 1970s, the development of the EU economy and the improvement of the living standards of its population became inconceivable without combating environmental pollution. In response to these processes, Directive 70/220 / EC was adopted at that time, which set uniform environmental standards for vehicle engines and, in order to reduce emissions of pollutants into the atmosphere, set emission limit values ${ }^{1}$. In 1972, the United Nations Conference on the Environment was held. This meeting paved the way for the implementation of a common environmental policy - the Commission has prepared large-scale action programs to reduce pollution and inconvenience and to manage environmental resources. In record time, as by Union standards, the European Union has taken many concrete measures.

In October 1972, the EEC member states adopted the Declaration on the Environmental Action Program. In the same year, the Heads of Government of the EU Member States decide on the competence of the EU, which includes the environmental sphere. All decisions in the new field of activity were based on the articles of the Treaty of Rome of 1957, which allowed to act in a field not specified in the treaty. Such an extension of competence was called the "spillover effect", and the new area of integration was regulated by directives. This proves that when there is pressure from public opinion and there are no deep-rooted national policies, the European institutions are able to carry out legislative work that can be compared to the same activities of an individual state.

In addition, based on the provisions of the constitutional documents, the EU's practical activities in the field of ecology began to be based on a special medium-term program of action on the environment. The program of actions in the field of environment is a political and legal document that defines the priority measures of the organization for the near future and sets specific goals and objectives that the EU achieves and fulfills, based on the current situation ${ }^{2}$. Thus, in early 1973, the First Environmental Action Program was adopted. It can be considered the first official document in which the basic principles of European policy in the field of environmental protection were formulated.

The first program identified six main tasks in the field of environmental protection:

1) reduction and, if possible, prevention of pollution;

2) maintaining the ecological balance of the biosphere;

3 ) prevention of damage to nature during the operation of its resources;

${ }^{1}$ Вишняков О.К. Право Європейського Союзу : підручник.. Одеса : Фенікс, 2013. C. 516.

2 Антонюк Н.В., Микієвич М.М. Свропейський Союз : політика, економіка, право : навчальний посібник. Львів, 2005. С. 268. 
4) improving working conditions through the normalization of the environment;

5) strengthening of environmental aspects in urban planning and land use;

6) search for ways to solve environmental problems together with states, especially in international organizations ${ }^{3}$. In our opinion, such programs are an important tool for regulating environmental issues.

In addition, it can be stated that in this period is the formation of environmental production standards. It is important to emphasize that such standards were aimed at preventing pollution at an early stage. Moreover, this opinion is confirmed by the fact that: scientific criteria are established to determine the degree of damage to the main forms of air, water and noise pollution in parallel with the standardization of methods and tools for measuring the damage caused; economic instruments of environmental policy are analyzed, taking into account the principle of "polluter pays"; there is a harmonization of environmental legislation of the Member States in the fight against technologies that pollute the environment, as well as the dissemination of environmental information.

According to the "polluter pays" principle, standards and fines are the main tools available to public authorities to avoid pollution. Standards include:

- environmental quality standards that have binding legal force and establish permissible levels of pollution that cannot be exceeded ${ }^{4}$;

- standards of goods (products), which establish the levels of pollutants that cannot be exceeded in the composition of goods or their emissions, or determine the qualities or characteristics of the design of goods, ways of their use. Where appropriate, product standards include features of testing, packaging, product labeling;

- standards for specific equipment, sometimes referred to as "process standards": (a) "emission standards"; (b) "equipment design standards"; (c) "operational standards".

The European Union is trying to standardize the calculation methods for setting the fines used in the Member States. In turn, each Member State must apply the "polluter pays" principle to all forms of pollution within its country. The fine is applied depending on the amount of pollution based on the relevant administrative procedures.

${ }^{3}$ Declaration of the Council of the European Communities and of the representatives of the Governments of the Member States meeting in the Council of 22 November 1973 on the programme of action of the European Communities on the environment. Official Journal. 1973. P. 1-2.

4 Микієвич М.М., Андрусевич Н.І., Будякова Т.О. Свропейське право навколишнього середовища : навчальний посібник. Львів : Львівський національний університет ім. І. Франка, 2004. С. 88.

Законодавство Європейського Союзу у сфері охорони навколишнього середовища : навчальний посібник / Ю.С. Голік, А.В. Войтенко, О.Е. Ілляш та ін. Полтава, 2009. С. 18. 
Thus, in addition to the use of fines, the principle also works with the introduction of environmental standards. Companies that have to meet accepted standards begin to apply the best available technologies and invest in their production process, making it less dangerous to the environment ${ }^{6}$. The EU's role in applying this principle is to ensure, through environmental taxes, fines, standards and (or) a system of environmental liability, that it is those who pollute the environment who compensate for the damage caused. The "polluter pays" principle should motivate the reduction of harmful effects on the environment and promote the development of technologies aimed at reducing the man-made load on the environment. It can be implemented through the approval of environmental standards. Businesses that address environmental standards must invest in production procedures. Thus it is established that the causative agent (polluter) really pays ${ }^{7}$. The European Union and the Member States, in their national environmental legislation, must apply the "polluter pays" principle, according to which natural and legal persons responsible for pollution must provide the necessary measures to avoid or reduce pollution.

The approach according to which the principle of "polluter pays" should be implemented in practice by introducing taxes on environmentally hazardous production is considered more balanced. Moreover, the principle is firmly entrenched in the EU legal system and case law (for example, The Queen v Secretary of State for the Environment and the Ministry of Agriculture, Fisheries and Food, ex parte HA Standley and Others and DGD Metson and $\mathrm{Others}^{8}$ ). This principle should guide the use of legal instruments to regulate environmental issues in the field of production in the law of the European Union.

In order to ensure the implementation of the First Program of Action, and as a confirmation of the establishment of standards and in order to prevent pollution of water bodies, eliminate harm to human health, monitor and control water quality, Council Directive 75/440 / EC on surface quality requirements was adopted. waters intended for the abstraction of drinking water in the

6 Энтин Л.М. Европейское право. Право Европейского Союза и правовое обеспечение защиты прав человека : учебник для вузов. 2-е изд. пересмотр. и доп. Москва : Норма, 2007. С. 786.

7 Вишняков О.К. Право Свропейського Союзу : підручник.. Одеса : Фенікс, 2013. C. 519.

${ }^{8}$ Judgment of the Court (Fifth Chamber) of 29 April 1999. - The Queen v Secretary of State for the Environment and Ministry of Agriculture, Fisheries and Food, ex parte H.A. Standley and Others and D.G.D. Metson and Others. - Reference for a preliminary ruling: High Court of Justice (England ans Wales), Queen's Bench Division - United Kingdom. - Directive 91/676/EEC - Protection of waters against pollution caused by nitrates from agricultural sources - Identification of waters affected by pollution Designation of vulnerable zones - Criteria - Validity in the light of the polluter pays principle, the principle that environmental damage should as a priority be rectified at source, the principle of proportionality and the right to property. Case C-293/97. European Court reports. 1999. P. I-02603. 
Member States ${ }^{9}$, as well as Council Directive 76/160 / EC on the quality of bathing water. O. Vyshnyakov proceeds from the fact that their purpose is to reduce water pollution used for drinking and bathing purposes and to protect them from further deterioration, which will contribute to the overall protection of the environment and public health ${ }^{10}$. At the same time, transport and industrial facilities have been identified as one of the main sources of air pollution, and the Community has harmonized similar acts on industrial equipment, in addition to harmonizing laws to combat engine noise and gas emissions, as well as local and transboundary air pollution, for which, in particular, air quality indicators were established and emissions restrictions were introduced by waste disposal facilities and industrial enterprises ${ }^{11}$.

EU legislation during the same period begins to regulate the production and use of chemicals, restricts the marketing and use of certain hazardous substances and drugs, establishes a procedure for controlling industrial waste, establishes procedures for coordinating programs to reduce and possibly eliminate pollution, and classifying, packaging and labeling hazardous substance, subject to registration ${ }^{12}$. The Ecolabel criteria are not based on one factor, use different studies, analyze the impact of products or services on the environment throughout its life cycle, from raw material production to production, distribution and disposal. In other words, the Ecolabel European Union logo helps manufacturers and suppliers of goods and services to be recognized for high standards.

Ecolabel is part of a broader Action Plan on Sustainable Consumption and Production and Sustainable Industrial Policy, adopted by the Commission in 2008, which contains a number of key recommendations for the development and implementation of a pan-European criterion for environmentally responsible public procurement. The process of developing such a criterion at the pan-European level should take into account all existing developments in establishing an environmental criterion within the framework of sustainable production and consumption, based on the life cycle of the product or service. Examples of potential sources of such a criterion are: Energy Star energy efficiency requirements for office equipment, environmental performance criteria that will be developed in the course of implementing measures under,

${ }^{9}$ Council Directive 75/440/EEC of 16 June 1975 concerning the quality required of surface water intended for the abstraction of drinking water in the Member States. Official Journal. L 194. 1975. P. 26-31.

${ }_{10}$ Вишняков О.К. Право Свропейського Союзу : підручник.. Одеса : Фенікс, 2013. C. 517.

${ }_{11}$ Council Directive 84/360/EEC of 28 June 1984 on the combating of air pollution from industrial plants. Official Journal. L 188. 1984. P. 20.

${ }_{12}$ Commission Decision 85/71/EEC of 21 December 1984 concerning the list of chemical substances notified pursuant to Council Directive 67/548/EEC on the approximation of laws, regulations and administrative provisions relating to the classification, packaging and labelling of dangerous substances. Official Journal. L 030. 1985. P. 33. 
for example, the provisions of the Directive on the promotion of environmentally friendly and energy efficient vehicles ${ }^{13}$.

Thus, it is safe to say that the introduction of prevention to prevent environmental problems and the establishment of minimum standards in the field of production has contributed to economic and social development within the EU.

The Second Program of Action of the European Communities, entitled "Continuation and Implementation of European Community Policy and the Program of Action on the Environment", was adopted in 1977 and was a de facto continuation and development of the First Program of Action. This program has identified the main objectives of the environmental policy of the European Communities, which are to prevent, reduce and avoid pollution; maintaining the ecological balance and ensuring the protection of the biosphere; avoiding the use of natural resources that could significantly affect the environment; search for solutions by states to environmental problems outside the Community, at the international level ${ }^{14}$. That is, while the First Program of Action focused on reducing and preventing pollution, improving the environment and living conditions, the Second Program of Action identified general actions to protect and improve the environment, including environmental impact assessment, consideration of economic aspects, implementation of research environmental protection projects.

From 1982 to 1986 there was a transition of multilateral environmental cooperation to a permanent interstate basis. The subject of regulation at this stage is the creation of a favorable ecological regime for wild fauna and flora, the conservation of wild birds and their habitats. A number of legal norms were aimed at preserving the viability of land, fresh and sea water elements and their inhabitants. The foundations are being laid for international cooperation in the field of protection of the marine environment and the establishment of a common legal regime for the protection of the waters surrounding Europe. Taking into account the importance of European rivers, measures are being taken to restore the ecological balance of the continent's waterways with the establishment of international coordination commissions. At this stage, the question of production waste in general and the means of their elimination was also raised, the permissible limits of production waste, as well as the possibility of their reuse were regulated.

During this period, the EU implements environmental research programs, such as STEP and EPOCH. It is safe to say that the period from 1951 to 1982 was marked by the formation of the European Union's policy on the

${ }^{13}$ Directive 2009/33/EC of the European Parliament and of the Council of 23 April 2009 on the promotion of clean and energy-efficient road transport vehicles (Text with EEA relevance). Official Journal. 2009. L 120. P. 5.

14 Микієвич М.М., Андрусевич Н.І., Будякова Т.О. Європейське право навколишнього середовища : навчальний посібник. Львів : Львівський національний університет ім. І. Франка, 2004. С. 11-12. 
environment and ways of its legal regulation, the establishment of minimum standards in the field of production.

\section{Environmental standards as a significant factor in economic growth}

The Fourth Environmental Action Program was adopted on 19 October 1987. It analyzes the additions made by the Single European Act to the Treaty of Rome and pays more attention to finding new opportunities for the integration of environmental policy into other Community policies ${ }^{15}$. It should be emphasized that the problems of environmental degradation prompted the EU in the Fourth Environmental Program to define strict environmental standards not just as an option for development, but as an imperative and a significant factor for future economic growth. sources of pollution, as well as unimpeded public access to environmental information.

Legislation to prevent and reduce the negative effects of the greenhouse effect, ozone depletion and climate change is becoming increasingly important. Following the reduction of industrial, transport and energy pollution within the EU, the procedure for the export and import of dangerous chemicals is being established. As an example, the Good Laboratory Practice standard is introduced as one of the attributes of environmental monitoring ${ }^{16}$.

Common environmental problems needed common solutions. Concerned about the serious impact on the competitiveness of its own economy, none of the European states could hope to solve their environmental problems on their own. Pollution control actually imposes certain costs on industrialists associated with the adaptation of their products or production processes. Such costs are greater the stricter the standards set by the government. If a Member State takes a strict and costly anti-pollution measure for its industry, it may thus punish itself vis-à-vis its competitors from other States who were less attentive to the damage caused by the pollution or who had other ideas about cost sharing. to combat pollution. Therefore, competition in the common market would be distorted. So it was important that there were uniform rules for all European producers.

To improve control over the effectiveness of environmental legislation, standardization and rationalization of reports on its implementation. The rapid development of genetics by the end of the XX century. caused the need to regulate the environmental consequences of the introduction of biotechnology in industry and the use of genetically modified organisms

15 Микієвич М.М., Андрусевич Н.І., Будякова Т.О. Свропейське право навколишнього середовища : навчальний посібник. Львів : Львівський національний університет ім. І. Франка, 2004. С. 14.

${ }^{16}$ Directive 2004/10/EC of the European Parliament and of the Council of 11 February 2004 on the harmonization of laws, regulations and administrative provisions relating to the application of the principles of good laboratory practice and the verification of their applications for tests on chemical substances. Official Journal. L 050. 2004. P. 44-59. 
$(\mathrm{GMO})^{17}$. In order to establish water quality control, determine water quality standards and protect water resources from EU pollution, Council Directive 91/271 / EC of 21 May $1991^{18}$ on urban waste water treatment was adopted. During these years, the EU case law on environmental protection was actively formed ${ }^{19}$. Thus, using the case law of the European Court of Justice, it was once again emphasized that the decision in the case of $\mathrm{ADBHU}^{20}$ formulated the provisions that environmental protection, despite its absence in Art. 2 of the Treaty among the goals of the Union, however, is the goal of the EU along with other goals directly enshrined in the Treaty ${ }^{21}$.

The 1991 UN Conference in Rio de Janeiro addressed the impact of economic development on the environment and had a significant impact on the further development of EU environmental policy. Not only the proximity of European countries to each other, but also their comparative socioeconomic development has become an argument in favor of EU action to protect the environment. Phenomena common to all European states - the expansion of industrial activity, the increase of urban population in megacities and the seizure of ever-larger plots of land, which have always been used and preserved for agricultural purposes, required appropriate measures and resources from Member States.

The Treaty establishing the European Union in 1992 set a new goal for the member states - to achieve balanced and sustainable development. Another goal of EU environmental policy has been identified - to provide international measures to address environmental issues at the regional and international levels ${ }^{22}$. It should be noted that the introduction of provisions governing environmental policy in the founding treaties of the European Union has contributed not only to the emergence of a large number of secondary law, but also to the institutional development of the EU. This consisted in the creation of special institutions dealing with environmental

17 Лозо В.И. Правовые основы экологической стратегии Европейского Союза (концепция, программное обеспечение, систематизация и комментарий действующего законодательства ЕС) : монография. Харків : Право, 2008. С. 76.

${ }_{18}$ Council Directive 91/271/EEC of 21 May 1991 concerning urban waste-water treatment. Official Journal. L 135. 1991. P. 40-52.

${ }^{19}$ Judgment of the Court (Second Chamber) of 23 September 2004. Commission of the European Communities v French Republic. Failure of a Member State to fulfil obligations Directive 91/271/EEC - Urban waste water treatment - Article 5(1) and (2) and Annex II Failure to identify sensitive areas - Meaning of «eutrophication» - Failure to implement more stringent treatment of discharges into sensitive areas. Case C-280/02. P. 2-4.

20 Judgment of the Court of 7 February 1985. Procureur de la République $\mathrm{v}$ Association de défense des brûleurs d'huiles usagées (ADBHU). Reference for a preliminary ruling: Tribunal de grande instance de Créteil - France. Free movement of goods - Waste oils. Case 240/83. URL: http://eur-lex.europa.eu/ legal-content/EN/TXT/?uri=CELEX\%3A61983CJ0240 (дата звернення 25.01.2021).

${ }^{21}$ Вишняков О.К. Право Європейського Союзу : підручник.. Одеса : Фенікс, 2013. 517 c.

Договір про Європейський Союз від 07.02.1992 p. URL: http://zakon4.rada.gov.ua/laws/show/994_029/page (дата звернення 25.01.2021). 
issues (for example, the European Environment Agency), as well as in the expansion of the powers of other bodies of the Union, their role in environmental protection. Thus, as defined by O. Vyshnyakov, since the signing of the Maastricht Treaty, the EU is gradually becoming an "environmental union" ${ }^{23}$. That is, EU member states were obliged to include environmental protection in legal acts of all areas of national policy.

The fourth phase, which covered the period from 1992 to 2001, saw a strong rise in the environmental movement in Western Europe, forcing the governments of the Member States to take significant steps forward in this area. The single market program has raised the status of environmental policy. It should be noted that the northern states and Germany differed in relatively high environmental standards.

The free movement of goods within the common market would also be affected if each Member State set different standards for goods intended for sale on its markets. A country that would set stricter standards than its neighbours, for example, with regard to limiting the noise of certain engines or emissions from engines, would restrain imports from other countries. Protection against pollution and noise could thus quickly become protection against foreign goods. In other words, national environmental policy could be used to create very significant barriers to the internal market.

Thus, EU environmental legislation introduced European standards for the national specification of environmental management systems, facilitated voluntary participation in the industrial sector of environmental management, involving economic circles; established the procedure for reaching agreements in the course of compliance with legal requirements, providing public access to the documents of the European Environment Agency, including through the information site "Nature" 24 . A program to support environmental associations is being adopted, and a European Consultative Forum on Environment and Sustainable Development is being set up to openly discuss environmental issues ${ }^{25}$. Combining the tasks of human health and environmental protection, the EU introduces a system of eco-labels $^{26}$, which initiated the establishment of strict environmental parameters for the release of goods and services for free circulation in the

${ }^{23}$ Vyshnyakov O.K., Yulinetska Y.V. EU Economic Law : Textbook. Odessa : Yurydychna literatura, 2011. P. 218.

24 Commission Decision 97/266/EC of 18 December 1996 concerning a site information format for proposed Natura 2000 sites. Official Journal. L 107. 1997. P. 1.

${ }^{25}$ Commission Decision of 26 November 1995 approving the programme for the eradication of rabies for 1997 presented by France and fixing the level of the Community's financial contribution (Only the French text is authentic). Official Journal. L 023. 1997. P. 10.

${ }^{26}$ Regulation (EC) № 1980/2000 of the European Parliament and of the Council of 17 July 2000 on a revised Community eco-label award scheme. Official Journal. L 237. 2000. P. 1. 
EU. The legal provision of nuclear safety is intensifying ${ }^{27}$, which already covers the domestic and industrial levels of protection of the population and workers from the containment of radon and nuclear radiation in general. To improve feedback, in the legal regulation of environmental protection and control over the effectiveness of legislation and its implementation, standardization and rationalization of notifications on the implementation of environmental regulations, the rules of questionnaires and the format of national programs in this area. To protect the air and improve the environmental performance of transport, a control scheme and procedure for confirming information on fuel economy and exhaust emissions in car marketing is being developed, much attention is paid to ensuring "wastefree" fuel, safe conditions for transportation and storage. A whole range of EU legal measures is aimed at forest protection, including the establishment of a forest fire protection regime with detailed rules for its implementation and a system of information on forest fires.

\section{Environmental standardization - legal regulation of environmental protection}

A new step forward in strengthening the legal framework for the EU's environmental strategy was taken in the 1997 Amsterdam Treaty, which reaffirmed the principle of "sustainable development". In addition, environmental integration is becoming a responsibility for Member States and candidate countries. The scope of legal regulation of environmental protection carried out by the EU includes such measures as environmental standardization, assessment of anthropogenic and man-made environmental impacts, collection and processing of environmental information, environmental monitoring, environmental certification, environmental management and environmental audit, mechanism development financing and protection of environmental rights ${ }^{28}$. In the context of enhanced cooperation, some Member States (Germany, Denmark, the Netherlands, Sweden, Belgium ${ }^{29}$ ) notify the EU of the total ban on particularly toxic substances and initiate the harmonization of laws on land transport of dangerous goods.

P. Kalinichenko, considering the mandatory nature of environmental integration, emphasizes that the EU has developed a system of environmental certification (Green Star System), which was adopted in 1998 at the European

${ }^{27}$ Council Decision 1999/175/Euratom of 25 January 1999 adopting a research and training programme (Euratom) in the field of nuclear energy (1998 to 2002). Official Journal. L 064. 1999. P. 142.

28 Лозо В.И. Правовые основы экологической стратегии Европейского Союза (концепция, программное обеспечение, систематизация и комментарий действующего законодательства ЕС) : монография. Харьков : Право, 2008. С. 81.

29 Дубовик О.Л. Кодификация экологического законодательства в ФРГ. Экологическое право. 2010. № 6. С. 40-43. 
Council in Cardiff under the program "Partnership for Integration"30. The EU's energy, transport and agricultural policies were among the first to fall under its influence. This type of integration then extended to domestic market development policy, fisheries, industry and finance.

Thus, the scope of legal regulation of environmental protection carried out by the EU includes such measures as environmental standardization, assessment of anthropogenic and man-made environmental impacts, collection and processing of environmental information, environmental monitoring, environmental certification, environmental management and environmental audit, development of a financing mechanism and protection of environmental rights. In addition, Article 37 of the 2000 Charter of Fundamental Rights of the European Union ${ }^{31}$ states that a high level of protection and improvement of the quality of the environment must be part of the Union's policy and achieved on the basis of the principle of sustainable development. The same opinion is expressed by S. Kashkin ${ }^{32}$.

At the international level, the EU takes an active legislative position in the field of environmental protection, participates in the activities of various intergovernmental conferences and international organizations on this issue, promotes UN measures for the transition to sustainable development.

The Laeken Declaration of 15 December 2001 "The Future of the European Union" set out more precise guidelines and a timetable for practical measures to reform and improve the EU's environmental strategy. An important point is the emergence of new geopolitical and environmental realities, which led us to highlight this stage, which covered the period from 2001 to 2012. According to the provisions of the founding treaty, the EU's environmental strategy is still based on Environmental Action Programs, which sets priorities and current measures for the near future. The EU's Sixth Environmental Program "Environment - 2010: Our Future, Our Choice", which was approved for 10 years immediately before the UN World Summit on Sustainable Development.

The legal basis for the functioning of the environmental management and audit system within the European Union is Regulation 761/2001, which establishes the conditions for the registration of objects by the organization, the requirements for environmental policies, programs and systems, the criteria for environmental audit and environmental audit procedures, as well

${ }^{30}$ Калиниченко П.А. Современные тенденции в развитии экологического права ЕС. Материалы семинара: Преподавание права Европейского Союза в российских ВУЗах-II. Москва : Статут, 2001. С. 207.

Хартія основних прав Європейського Союзу від 07.12.2000 p. URL: http://zakon3.rada.gov.ua/laws/show/994_524 (дата звернення 25.01.2021).

32 Кашкин С., Калиниченко П. Новая программа действий Европейского сообщества в области окружающей среды. Российская юстиция. 2003. № 8. С. 19. 
as introduces requirements for environmental auditors and eco-auditors ${ }^{33}$. It has been adopted to assist businesses and organizations and aims to improve corporate governance, creating common technical standards for environmental policies for businesses operating in the European Union. At the same time, Regulation 761/2001 contributes to strengthening the compliance of companies with environmental requirements by Member States and the EU.

In 2009, the Council of Europe and the European Parliament adopted at first reading the decision to reform two key EU instruments in the area of sustainable consumption and production management - Ecolabel and the Environmental Management and Audit System (EMAS). Both schemes will continue to be voluntary.

The Seventh Action Program introduces a balanced mix of incentives for consumers and businesses (including small and medium-sized enterprises), market-based instruments and rules to reduce the environmental impact of production and its products. It is this document that confirms the relevance of regulating the sphere of production and is an indicator of the importance of intensifying environmental policy in this area.

Today's realities are attempts to increase the effectiveness of EU environmental legislation, including by updating and codifying it. More attention has been paid in the EU to the protection of environmental rights of citizens, as well as the integration of environmental policy into other areas of the European Union.

The environmental standards and programs developed in the European Union are of interest not only to integration associations in other regions, but also to neighboring countries, including Ukraine, which are extremely interested in the development and improvement of national environmental legislation. We have every reason to consider the EU as a model for one of the most effective environmental regulations in the world. Thus, thanks to the EU, for more than half a century Europe has been living in a world of ecological achievements: during this period the legal basis of the ecological strategy has been created, the methods of nature protection are being improved, and the quality of the environment has begun to improve. The $\mathrm{EU}$, as a leader in environmental cooperation in Europe, is actively involved in global environmental activities under the auspices of the United Nations.

The main directions of the EU environmental strategy at this stage were: legal regulation of anthropogenic impact on the environment and monitoring of its condition; environmental management and audit; standardization and certification of the relationship between society and nature; protection of environmental human rights; improving product quality; waste reduction.

${ }^{33}$ Directive 2000/60/EC of the European Parliament and of the Council of 23 October 2000 establishing a framework for Community action in the field of water policy. Official Journal. 2000. L 327. P. 10. 
The emphasis in the fight against pollution is on the costs of industrialists, which are associated with the adaptation of their products or production processes to market conditions - it was important that all European producers have uniform rules in the internal market.

Standards in the field of production are introduced: pollution prevention, prevention and elimination of damage to the environment at the expense of the pollutant; determining the degree of damage to air, water and noise pollution in parallel with the standardization of methods and tools for measuring the damage caused; dissemination of environmental information. Strict environmental standards are set as a factor of economic growth, as well as unimpeded public access to environmental information.

\section{CONCLUSIONS}

The environmental standards and programs developed in the European Union are of interest not only to integration associations in other regions, but also to neighboring countries, including Ukraine, which are extremely interested in the development and improvement of national environmental legislation. We have every reason to consider the EU as a model for one of the most effective environmental regulations in the world. Thanks to the EU, for more than half a century Europe has been living in a world of ecological achievements: during this period the legal basis of the ecological strategy has been created, the methods of nature protection are being improved, and the quality of the environment has begun to improve. The EU, as a leader in environmental cooperation in Europe, is actively involved in global environmental activities under the auspices of the United Nations.

Analyzing the formation of environmental standards of production in the law of the European Union revealed the following trends: environmental policy should be interrelated with economic and social development, and progress should take into account the interests of society with minimal impact on the environment; production standards are not an obstacle but a development factor that prevents negative environmental consequences, given the measures taken or planned at national or local level that are important for the formation of EU secondary law; it is impossible to avoid pollution, but it is possible to create conditions for its reduction or to abandon nature use, which violates the ecological balance; it is necessary to constantly promote and support scientific and technological research in the field of environmental protection; an important place is given to the coordination and harmonization of environmental policy based on the procedure of informing about the state of the environment.

\section{SUMMARY}

The article is analyzed establishment of environmental standards of production in the law of the European Union, identified the stages of its 
development, determined the state of the environmental standards of production.

The article deals with environmental protection. It's a key issue in the political and legal space and an important issue that exists at the national, regional, European and international levels.

The EU has become a basic platform for solving the global problems facing humanity, including the establishment of the legal framework for a single environmental strategy and the development of European principles and national systems of environmental legislation, as well as the establishment and implementation of environmental standards.

It is noted that the EU in its legislation introduces a balanced combination of incentives for consumers and businesses, market instruments and rules to reduce the environmental impact of production and its products. This confirms the relevance of regulating the sphere of production and is an indicator of the importance of intensifying environmental policy in this area. The study found that standards are the main tool to avoid pollution.

\section{REFERENCES}

1. Антонюк Н.В., Микієвич М.М. Європейський Союз : політика, економіка, право : навчальний посібник. Львів, 2005. 532 с.

2. Вишняков О.К. Право Європейського Союзу : підручник. Одеса : Фенікс, 2013. 883 с.

3. Договір про Європейський Союз від 07.02.1992 p. URL: http://zakon4.rada.gov.ua/laws/show/994_029/page (дата звернення 25.01.2021).

4. Дубовик О.Л. Кодификация экологического законодательства в ФРГ. Экологическое право. 2010. № 6. С. 40-43.

5. Законодавство Європейського Союзу у сфері охорони навколишнього середовища : навчальний посібник / Ю.С. Голік, А.В. Войтенко, О.Е. Ілляш та ін. Полтава, 2009. 170 с.

6. Калиниченко П.А. Современные тенденции в развитии экологического права ЕС. Материалы семинара: Преподавание права Европейского Союза в российских ВУЗах-II. Москва : Статут, 2001. C. 207-211.

7. Кашкин С., Калиниченко П. Новая программа действий Европейского сообщества в области окружающей среды. Российская юстиичи. 2003. № 8. С. 19-20.

8. Лозо В.И. Правовые основы экологической стратегии Европейского Союза (концепция, программное обеспечение, систематизация и комментарий действующего законодательства ЕС) : монография. Харьков : Право, 2008. 368 с.

9. Микієвич М.М., Андрусевич Н.I., Будякова Т.О. Свропейське право навколишнього середовища : навчальний посібник. Львів : Львівський національний університет ім. І. Франка, 2004. 256 с. 
10. Хартія основних прав Європейського Союзу від 07.12.2000 p. URL: http://zakon3.rada.gov.ua/laws/show/994_524 (дата звернення 25.01.2021).

11.Энтин Л.М. Европейское право. Право Европейского Союза и правовое обеспечение защиты прав человека : учебник для вузов. 2-е изд. пересмотр. и доп. Москва : Норма, 2007. 960 с.

12. Commission Decision 85/71/EEC of 21 December 1984 concerning the list of chemical substances notified pursuant to Council Directive 67/548/EEC on the approximation of laws, regulations and administrative provisions relating to the classification, packaging and labelling of dangerous substances. Official Journal. L 030. 1985. P. 33-34.

13. Commission Decision 97/266/EC of 18 December 1996 concerning a site information format for proposed Natura 2000 sites. Official Journal. L 107. 1997. P. 1-156.

14. Commission Decision of 26 November 1995 approving the programme for the eradication of rabies for 1997 presented by France and fixing the level of the Community's financial contribution (Only the French text is authentic). Official Journal. L 023. 1997. P. 10.

15. Council Decision 1999/175/Euratom of 25 January 1999 adopting a research and training programme (Euratom) in the field of nuclear energy (1998 to 2002). Official Journal. L 064. 1999. P. 142-153.

16. Council Directive 75/440/EEC of 16 June 1975 concerning the quality required of surface water intended for the abstraction of drinking water in the Member States. Official Journal. L 194. 1975. P. 26-31.

17. Council Directive 84/360/EEC of 28 June 1984 on the combating of air pollution from industrial plants. Official Journal. L 188. 1984. P. 20-25.

18. Council Directive 91/271/EEC of 21 May 1991 concerning urban waste-water treatment . Official Journal. L 135. 1991. P. 40-52.

19. Declaration of the Council of the European Communities and of the representatives of the Governments of the Member States meeting in the Council of 22 November 1973 on the programme of action of the European Communities on the environment. Official Journal. C 112. 1973. P. 1-53.

20. Directive 2004/10/EC of the European Parliament and of the Council of 11 February 2004 on the harmonization of laws, regulations and administrative provisions relating to the application of the principles of good laboratory practice and the verification of their applications for tests on chemical substances. Official Journal. L 050. 2004. P. 44-59.

21. Directive 2009/33/EC of the European Parliament and of the Council of 23 April 2009 on the promotion of clean and energy-efficient road transport vehicles (Text with EEA relevance). Official Journal. 2009. L 120. P. 5-12.

22. Judgment of the Court (Fifth Chamber) of 29 April 1999. - The Queen v Secretary of State for the Environment and Ministry of Agriculture, Fisheries and Food, ex parte H.A. Standley and Others and D.G.D. Metson 
and Others. - Reference for a preliminary ruling: High Court of Justice (England ans Wales), Queen's Bench Division - United Kingdom. - Directive 91/676/EEC - Protection of waters against pollution caused by nitrates from agricultural sources - Identification of waters affected by pollution Designation of vulnerable zones - Criteria - Validity in the light of the polluter pays principle, the principle that environmental damage should as a priority be rectified at source, the principle of proportionality and the right to property. Case C-293/97. European Court reports. 1999. P. I-02603.

23. Judgment of the Court (Second Chamber) of 23 September 2004. Commission of the European Communities v French Republic. Failure of a Member State to fulfil obligations - Directive 91/271/EEC - Urban waste water treatment - Article 5(1) and (2) and Annex II - Failure to identify sensitive areas - Meaning of «eutrophication» - Failure to implement more stringent treatment of discharges into sensitive areas. Case C-280/02. 37 p.

24. Judgment of the Court of 7 February 1985. Procureur de la République $\mathrm{v}$ Association de défense des brûleurs d'huiles usagées (ADBHU). Reference for a preliminary ruling: Tribunal de grande instance de Créteil - France. Free movement of goods - Waste oils. Case 240/83. URL: $\quad$ http://eur-lex.europa.eu/legal-content/EN/TXT/?uri=CELEX\% 3А61983CJ0240 (дата звернення 25.01.2021).

25. Regulation (EC) № 1980/2000 of the European Parliament and of the Council of 17 July 2000 on a revised Community eco-label award scheme. Official Journal. L 237. 2000. P. 1-12.

26. Vyshnyakov O.K., Yulinetska Y.V. EU Economic Law : Textbook. Odessa : Yurydychna literatura, 2011.312 p.

\section{Information about the author: Kachuriner V. L.,}

Ph. D. in Law, Associate Professor, Associate Professor at the Department of the International and Comparative Law

International Humanitarian University 33, Fontanska Doroha str., Odesa, 65009, Ukraine 